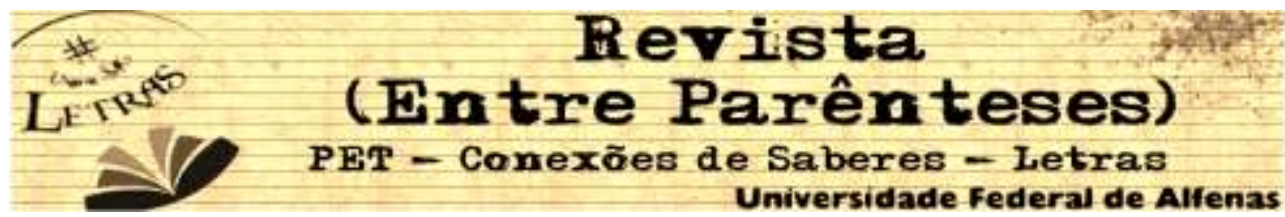

\title{
UM ENSAIO DA FICÇÃO RUFFATIANA
}

\section{A REHEARSAL OF THE "RUFFATIANA" FICTION}

\author{
Júlia de Mello Silva Oliveira ${ }^{1}$ \\ Universidade Federal de Alfenas - Unifal \\ julia_mello_silva@hotmail.com \\ Prof. Dr. Eloésio Paulo dos Reis² \\ Universidade Federal de Alfenas - Unifal \\ eloesio@gmail.com
}

Resumo: Luiz Ruffato, muito antes de lograr reconhecimento como autor de ficção, publicou algumas obras literárias. Uma delas, o conto "Olívia", que figura na coletânea Marginais do Pomba, contém elementos da técnica estético-representacional que viria a ser empregada pelo autor em todo o seu projeto literário, em especial no romance Eles eram muitos cavalos, que pode ser considerado, ao menos até o momento, uma síntese desse projeto.

Palavras-chave: Literatura brasileira; Luiz Ruffato; Conto.

Abstract: Luiz Ruffato, before he was rewarded as a fiction author, he had already published some literary works. One of them, a short story called "Olívia", which is a piece of the set "Marginais do Pomba", has elements of the "esthetic-representational" technique that took place throughout the whole author's literary project, mainly in Eles eram muitos cavalos. So far, this work has been regarded as a briefing of this project.

Key-words: Brazilian literature; Luiz Ruffato; Short story.

\section{Introdução}

O desenvolvimento da prosa ficcional costuma dar-se por meio de transformações.

Desde o surgimento do romance, como forma emblemática de se romper com a dicção (neo)clássica e de reinventar o futuro da literatura, e até a contemporaneidade, muitas fôrmas literárias apareceram e se metamorfosearam.

\footnotetext{
${ }^{1}$ Bacharel e Licencianda em Letras. Membro do grupo de pesquisa Literatura, Linguagem e Outros Saberes. Orientada do Prof.Dr. Eloésio Paulo dos Reis.

${ }^{2}$ Doutor em Letras pela Universidade Estadual de Campinas - Unicamp. Professor da Universidade Federal de Alfenas - Unifal.
}

$1 \frac{\text { Revista (Entre Parênteses) }}{\operatorname{Volume~1,~Número~5,~2016~-~ISSN~2238-4502~}}$




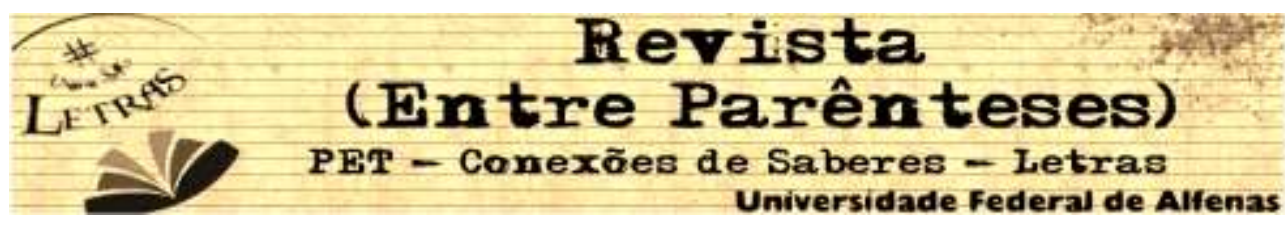

Uma delas é o conto, que, precursor do romance, guarda com ele elementos estruturais comuns. Os dois gêneros diferenciam-se não só pela extensão, mas principalmente pelo manejo ou tratamento dos elementos da poética narrativa. Daí dizer-se que a relação conto-romance é uma relação de contato, de fronteira.

Essa relação faz do conto, segundo Massaud Moisés (2006, p.37), "do prisma de sua história e de sua essência, a matriz da novela e do romance". É claro que há contos que formam uma unidade tão completa e fechada que não são passíveis de desenvolvimento maior que a estrutura na qual foram concebidos, porque nasceram essencialmente contos. Assim como existem romances cuja elaboração envolve tamanha complexidade que, se fossem reduzidos a contos, sua substância se perderia. No entanto, existem narrativas que, transitando entre os dois gêneros, podem ser adaptadas a esquema diverso daquele em que foram concebidas.

Alguns autores escrevem situando-se nessa fronteira porque utilizam o conto como meio de experimentar a composição do romance. Isso pode dar-se de maneiras diversas. Eça de Queirós, por exemplo, a partir de uma ampliação de seu conto Civilização e da complexificação do tratamento dado aos seus elementos narrativos estruturais, escreveu $A$ cidade e as serras. Graciliano Ramos, embora por questões econômico-editoriais, concebe Vidas secas a partir de capítulos, cada um dos quais tem a estrutura de um conto, tanto que podem ser lidos separadamente. Clarice Lispector se utiliza do conto como meio de desenvolver sua particular dicção romanesca e de testar contextos e personagens de seus romances: o conto/crônica As águas do mundo, publicado em Felicidade clandestina, é trecho literal de Uma aprendizagem ou o livro dos prazeres.

No caso de Olívia, conto de Luiz Ruffato que será aqui analisado, estamos falando de uma narrativa em que aparentemente o jovem autor tateava o tema e a estética que acabariam por nortear seu projeto literário, configurado em sua forma mais desenvolvida no romance Eles eram muitos cavalos. Por isso, Olívia pode ser visto como uma das primeiras matrizes da ficção do autor.

Ruffato, antes de ser conhecido e obter significativo prestígio no panorama literário brasileiro, escreveu poemas e contos, alguns dos quais reunidos em obras de 


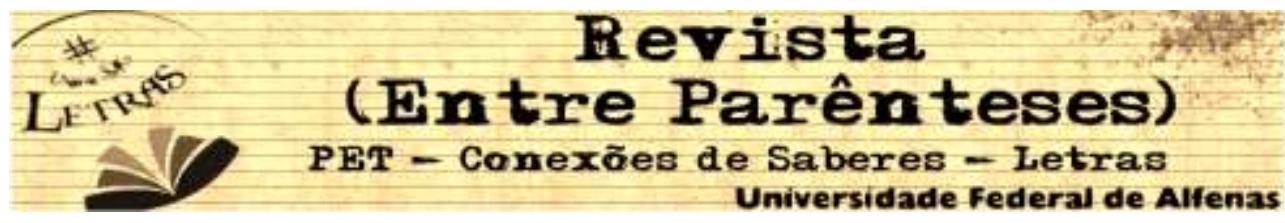

sua autoria, como O Homem que tece (1979) e Cotidiano do medo (1984), tendo sido outros publicados, de maneira avulsa, em coletâneas e antologias.

Uma das primeiras aparições do Ruffato ficcionista foi a coletânea Marginais do pomba, publicada em 1985, que reunia trabalhos de escritores de algum modo ligados a Cataguases, cidade natal do escritor. O texto de Ruffato nessa coletânea, Olívia, é uma narrativa cuja elaboração contém, na forma embrionária, alguns aspectos da técnica estético-representacional ruffatiana, na época em gestação, e que se consolidaria em Eles eram muitos cavalos (2001), seria posteriormente desenvolvida na pentalogia Inferno Provisório. É possível identificar em Olívia algumas das características da dicção que caracteriza o estilo de Luiz Ruffato em sua fase madura - considerando como tal, aqui, a época de publicação de seus livros hoje reconhecidos como obras relevantes da ficção brasileira, o que inclui (especialmente no caso de Eles eram muitos cavalos) traduções para os principais idiomas ocidentais. Há evidências de que Ruffato experimenta, no conto em questão, recursos cujo emprego seria confirmado e ampliado em suas obras mais desenvolvidas.

Essa experimentação não fica à deriva, de modo algum, no processo criativo do autor. Leitor atento e empenhado da tradição literária, especialmente da literatura brasileira moderna, Ruffato pratica em sua escrita algumas técnicas estéticorepresentacionais, formas de elaboração da linguagem, utilizadas por escritores modernos, incluindo os vanguardistas, e testa-as em sua própria obra, a qual, antes de ser um projeto especificamente literário, consistia em um projeto temático: falar dos desafortunados, dos explorados economicamente.

Olívia, como um texto do escritor em formação, não foge a essa proposta estético-temática; antes, já anuncia as questões que serão abordadas pelas obras publicadas mais tarde pelo autor: desigualdade social, falta de oportunidade, as misérias do cotidiano, insatisfação diante das circunstâncias da vida e suas fatalidades.

\section{Um laboratório ficcional}




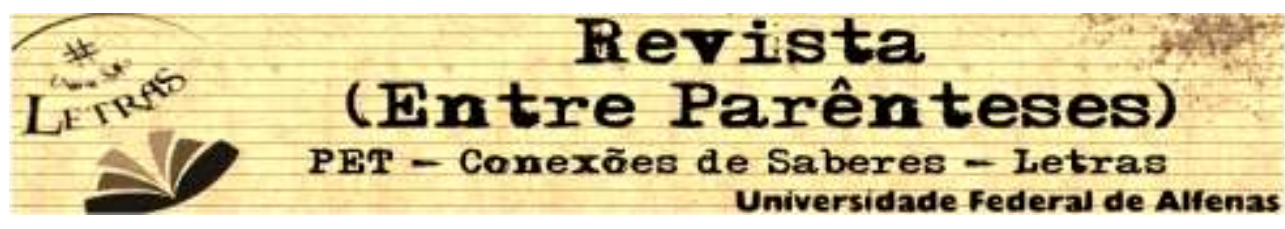

O conto narra o fim-de-semana em que Francisco termina sua relação com Olívia. Ele se havia mudado, por influência dos amigos Armando e Sérgio, para a cidade onde Olívia morava. Os dois amigos queriam se mudar para essa cidade porque "tinham estudado e não queriam morrer naquele fim de mundo" onde moravam anteriormente. Eles perguntaram se Francisco queria também mudar-se e, como este "não tinha nada a perder mesmo", segue-os. Mas Armando e Sérgio não ficaram na cidade, por não conseguirem trabalho e acabam voltando para o local de origem, onde o primeiro se torna vereador e dono de farmácia e o segundo se emprega no Banco do Brasil. Francisco, portanto, é o único que fica na cidade da namorada. Mas ele tampouco consegue sucesso por lá: "Néris. Porríssima nenhuma". Por causa disso, torna-se um insatisfeito, infeliz, que não se reconhece mais e que precisa ficar sozinho, o que implica terminar seu relacionamento com Olívia e ir embora da cidade. O enredo gira em torno das sucessivas tentativas de término desse namoro.

Mas esse enredo, conquanto à primeira vista pareça uma história simples, sentimental e ingênua, próxima do clichê, está envolvido em uma interessante concepção formal. Ele foge ao esquema narrativo mais tradicional, evidenciando da parte do jovem escritor não só o conhecimento do "estado da arte" da ficção brasileira na época, mas um empenho no sentido de sintonizar sua própria escrita ficcional com as necessidades estéticas e os impasses técnicos que informavam os principais escritores em atividade na literatura brasileira dos anos 1970 e 1980. Ruffato, enfim, demonstrava estar em dia com os problemas teóricos e estéticos da contística naquele ocaso do regime militar iniciado em 1964.

Essa sintonia com as necessidades estéticas pós-64 atende, por exemplo, em Olívia, ao "esfacelamento do enredo" e à "desconvencionalização dos caracteres" - segundo Fábio Lucas (1983, p. 107), características da ficção daquela época, voltada para "o próprio processo de escrita, para um referencial menos externo e mais voltado para o próprio processo narrativo".

Trata-se de um "estar em dia" com as "contribuições de linha experimental e renovadora" que, segundo Antônio Candido (1989, p.208), deram o timbre dos anos 1960 e, sobretudo, 1970. Para esse mesmo crítico (1989, pp. 208-209), na época não 


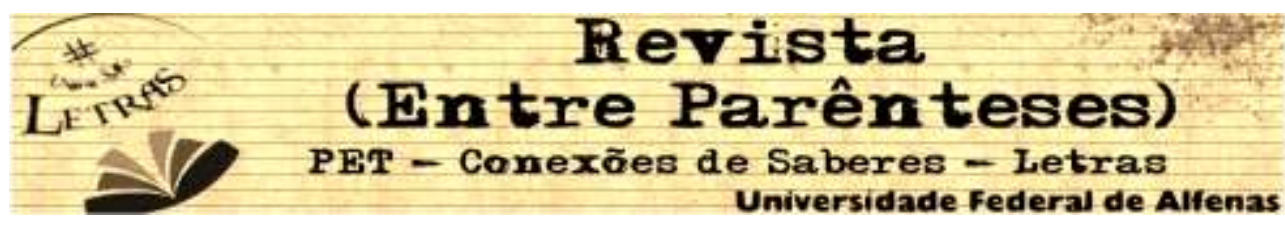

coexistem mais, pacificamente, os gêneros conto e romance, limitados por suas características específicas, mas eles desdobram-se, "deixam de ser gêneros, incorporando técnicas e linguagens nunca dantes imaginadas dentro de suas fronteiras". Tornam-se textos indefiníveis: "romances que mais parecem reportagens; contos que não se distinguem de poemas ou crônicas, semeados de sinais e fotomontagens; (...) textos feitos com justaposição de recortes, documentos, lembranças, reflexões de toda a sorte". E tal estética, ainda sob o olhar de Candido, esteve assim delineada em razão do contato da literatura com o boom editorial da época, com a propaganda, a televisão, as vanguardas poéticas que foram sendo incorporadas à tradição desde o fim dos anos 1950, especialmente o Concretismo.

Já distante de ser uma "forma simples" pura, mas atualizada e encontrada com a "forma artística" (JOLLES, 1976, pp.192-197), o conto moderno, principalmente o pós-64, adquire, segundo Fábio Lucas (1983, p. 155), marcas próprias de seu tempo: "os discursos fragmentados, as técnicas de montagem inspiradas no cinema, (...) a tendência ao estilo coloquial". Recursos como o fluxo do monólogo; a gíria; a abolição das diferenças entre o falado e o escrito; o ritmo galopante da escrita, que acerta o passo com o pensamento; a utilização dos sinais gráficos; o uso de figuras e fotografias, não apenas inseridos no texto, mas fazendo parte do projeto gráfico dos livros; tudo isso, segundo Candido (1989, pp. 209-210), são técnicas, inventadas ou recicladas, que se empregam na composição da contística no período em questão, como em Paulinho Perna-Torta, de João Antônio, A morte de D.J em Paris, de Roberto Drummond, e alguns dos principais contos de Rubem Fonseca.

Walnice Galvão (1983, pp.170-171) considerou as mesmas técnicas como caracterizadoras da composição estética do conto moderno sob a ótica da mímesis dos novos meios de comunicação, resultantes da aceleração que marca a segunda Revolução Industrial: a imitação da linguagem telegráfica, a fragmentação do discurso, a imitação das tomadas e dos cortes cinematográficos.

Regina Dalcastagnè (2001, p.8), em seu artigo Renovação e permanência - o conto brasileiro da última década, também considera a influência do cinema, os diálogos rápidos, a concisão de estilo, a linguagem coloquial, a plasticidade da 


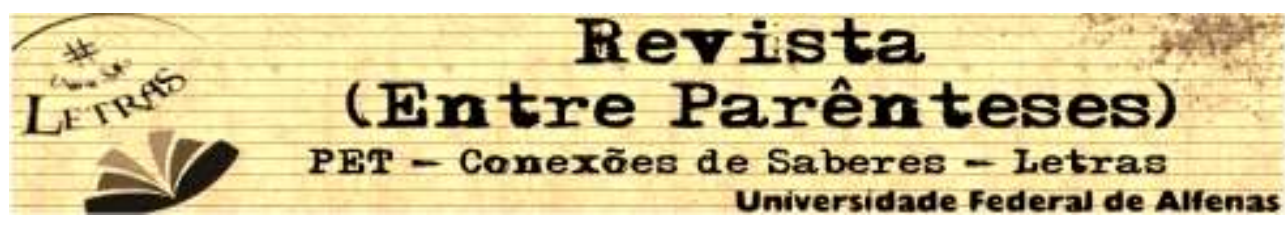

narrativa em que as cenas do cotidiano se desenrolam diante dos olhos, como algumas das características marcantes desse conto que se desenvolveu a partir do boom editorial dos anos 70. A estudiosa menciona Luiz Ruffato em seu artigo, no subtítulo "novos autores", caracterizando-o como escritor que centra suas narrativas nas cenas, retratadas a partir de um "realismo cru", da vida cotidiana.

Enquanto um bom leitor, observador e estudioso da tradição literária moderna, Luiz Ruffato trabalha, já em Olívia, o debruçar-se da narrativa sobre sua própria composição a partir da reciclagem das técnicas do esfacelamento/fragmentação do enredo, da justaposição dos fragmentos de texto, da gíria, de uma ainda tímida e parcial oralização da escrita, dos traços líricos imiscuídos na configuração narrativa.

Em Olívia se percebe uma construção fragmentária, e os fragmentos não são organizados de modo temporalmente linear. O narrador ora se alterna entre dois focos narrativos, ora deixa seu discurso ser entremeado pelo das personagens Francisco e Olívia. O autor também já explora alguns recursos visuais, como a alternância tipográfica, assim como emprega o recurso da colagem.

De maneira semelhante, por exemplo, à de alguns contos de Brás, Bexiga e Barra Funda, de Alcântara Machado, a narrativa de Olívia se estrutura por meio de fragmentos de texto que se vão completando e, no mesmo passo, completando o sentido do relato. Cada fragmento é o desvelar do motivo pelo qual o fato principal está ocorrendo. Assim, é preciso considerar o conjunto dos fragmentos para que a narrativa pouco a pouco revele a explicação, o sentido daquele acontecimento central.

A estrutura fragmentária do texto faz que os elementos tradicionais do conto sejam apresentados de maneira descontínua. O enredo não-linear, que se desenrola nos fragmentos, desorganiza a apresentação do tempo, espaço e personagens, de modo que eles vão sendo desvelados, ao longo da narrativa, de modo intermitente, e não cronologicamente.

O fragmento inicial, que apresenta, num domingo de agosto, o momento no qual Olívia chega ao apartamento de Francisco, é temporalmente interrompido pelo fragmento seguinte, que narra, no passado, o momento em que Francisco e Olívia se 


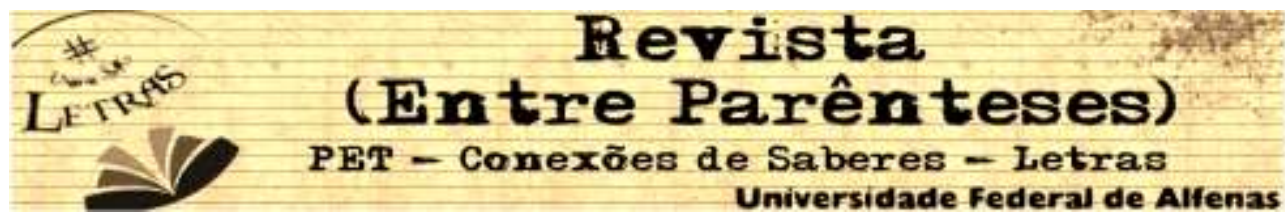

haviam conhecido. Esse momento é seguido por um terceiro fragmento que retorna à situação inicial, no apartamento de Francisco, no domingo, quando ele comunica à moça a intenção de pôr fim ao relacionamento de ambos, porque não estava sendo autêntico, porque não estava se reconhecendo e porque, por isso, precisava ficar sozinho. Em seguida, no quarto fragmento, há o diálogo, não marcado temporalmente, mas que sugere ser uma continuação do terceiro fragmento, em que Francisco conta a Olívia como e por que chegara à cidade dela e como não conseguira se estabelecer economicamente lá. O quinto fragmento relata uma cena num barzinho, no sábado, dia anterior à ida de Olívia ao apartamento de Francisco, em que eles têm uma discussão: ele diz que ela o estava sufocando e pede que ela vá embora, mas depois segue-a e combina com ela a ida a seu apartamento no domingo, para conversarem melhor e esclarecerem tudo. O sexto fragmento sugere ser continuação do quarto, em que os namorados fazem sexo e adormecem, depois o rapaz se levanta antes da moça, fecha a porta do apartamento, vai perambular pela cidade até ter certeza de que ela não o esperava mais e, quando volta, encontra um bilhete dizendo que Olívia o encontraria "em frente ao 'nosso' grupo". No último fragmento, então, já no dia seguinte, segunda-feira, ele vai ao encontro marcado no bilhete e finalmente termina o namoro.

Os sete fragmentos de texto que compõem o conto, como se vê não se organizam linearmente, intercalam-se o presente e o passado. E os fragmentos que remetem ao passado vão elucidando e preenchendo as lacunas daqueles que narram a situação presente, construindo o quebra-cabeças do que aconteceu com o casal naquele domingo e na segunda-feira.

A narração desse fato central e de suas intermitências se biparte, inicialmente, em dois focos: ora o narrador conta a história sob a perspectiva de Olívia, ora sob a perspectiva de Francisco. Começa, por exemplo, contando sobre como ele se sentia em seu apartamento durante o entardecer e anoitecer do "insípido domingo de agosto" até o momento em que Olívia toca sua campainha. Então o narrador, no mesmo fragmento, começa a narrar a chegada de Olívia ao edifício em que Francisco morava e o momento em que ela toca a campainha. 


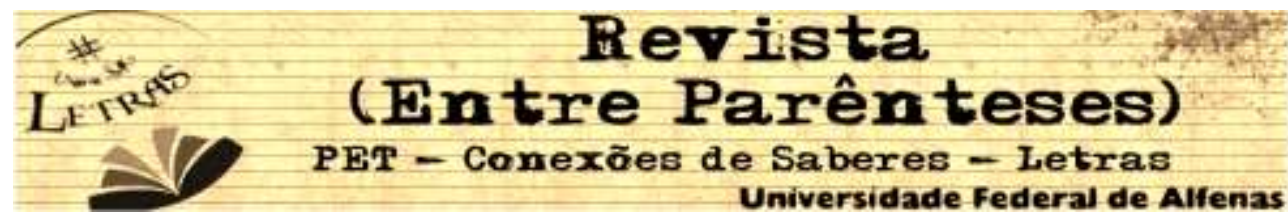

Depois essa divisão dos focos narrativos continua, não mais com uma bipartição do olhar do narrador, mas a partir da interpenetração dos discursos do narrador e das duas personagens. Esses discursos que se misturam textualmente são identificados por meio da alternância/alteração tipográfica, já que o discurso de Olívia aparece em negrito e o de Francisco, assim como o do narrador, aparece em fonte padrão:

Ele estava encostado num poste, esperando o ônibus, quando ela chegou. $\mathrm{O}$ ônibus da Cidade Universitária já passou? Olhou-a. Desajeitada, tímida. Um vestido de seda indiano lhe caía sobre o corpo. Sandálias de couro; bolsa de crochê deformada pelo peso de livros? De cadernos? Os cabelos eram presos por dois singelos pregadores em forma de borboleta. Não, não passou ainda não. Puxou conversa: o que você faz na universidade? História. Coitada, vai formar e passar fome. Quem Ihe disse isso? Ele sorriu. Ninguém. Eu estou dizendo. (RUFFATO, 1985, p.70)

Esses discursos são concebidos pelo autor por meio de uma linguagem que se aproxima da oralidade. Assim, além do emprego de gírias e palavrões, observam-se construções como "Tá legal", "Toma, dá um tapa", "Vai tomar no cu", em que a redução do verbo "está" para "tá", ou o imperativo em terceira pessoa substituído pela conjugação em segunda, são típicos dos contextos de comunicação oral.

O discurso do narrador, especificamente, está impregnado de uma discreta notação poética. É o que se observa, por exemplo, no fragmento final do conto, quando o narrador descreve a cena em que Olívia vai caminhando por entre os alunos do grupo escolar ao ouvir de Francisco que ele queria dar um rumo à própria vida e que por isso estava terminando o relacionamento entre os dois, sem mais porquês:

Olívia, repetiu, eu só vim aqui pra te pedir uma coisa: não me procure mais, tá legal? Nunca mais. E desta vez é definitivo. Mas, por quê? Não tem porquê? Não, Olívia, não tem porquê. Eu quero dar um rumo na minha vida. Só isto. De repente, crianças azuis e brancas foram vomitadas pelo portão do grupo e se meteram entre os dois. Lágrimas boiaram em seus olhos, enquanto ele desaparecia por entre os carros na avenida. Sem uma atitude, permaneceu ancorada ao muro, enquanto escolares olhavam espantados. Por fim, saiu andando devagar, acompanhada por um cortejo de crianças, que, improvisadas, assistiam seu desespero. (RUFFATO, 1985, pp.72-73)

Outro recurso estético é utilizado somente uma vez ao longo do texto, mas se torna tão importante quanto os outros: a colagem. Quando Olívia, depois de ter 


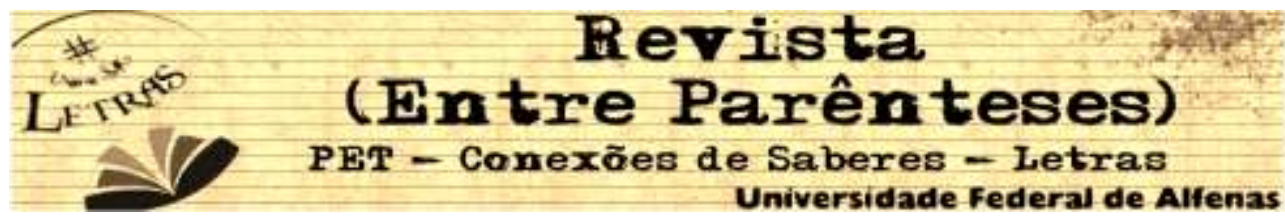

feito sexo com Francisco, adormecer, acordar e perceber a ausência dele no apartamento, deixará um bilhete marcando o encontro "em frente ao 'nosso' grupo"; o autor transcreve esse bilhete imitando a disposição do texto no papel, como Olívia o havia redigido.

Tanto a utilização desse recurso como a dos demais levam a crer que o autor problematiza, como os modernistas, o modo de articulação entre literatura e realidade, reciclando (devido à exaustão das formas e à consciência da dificuldade de se obterem inovações da forma literária na contemporaneidade) alguns dos recursos estético-representacionais próprios do Modernismo.

A composição caleidoscópica, fragmentária, o anacronismo, a interpenetração discursiva, bem como sua representação por meio da notação diferente para as falas das personagens, o discreto lirismo contido na voz do narrador, a colagem, o emprego de uma escrita oralizada, tudo isso já ocorria em textos modernos como Memórias sentimentais de João Miramar, de Oswald de Andrade, Zero, de Ignácio de Loyola Brandão, e $A$ festa, de Ivan Ângelo, e será reiterado pela obra posterior de Ruffato, sobretudo em Eles eram muitos cavalos.

Em depoimento ao Jornal dos Lagos em 1984, o autor já manifestava sua opinião sobre o fazer poético, sobre a concepção da obra literária "como o projeto de um edifício: detalhadamente elaborado. Matematicamente elaborado". No mesmo texto, o futuro romancista diz que o início de um conto prescinde de uma ideia definida, que a obra vai sendo pensada e refletida pelo autor até que possa ser passada para o papel. No entanto, ele explica, "essas ideias aleatórias nunca são passadas para a forma de poema ou de conto gratuitamente. Elas passam por um processo de prévia elaboração até que, sentindo-a definitiva, passo-a para o papel, onde será exaustivamente trabalhada". Desde quando ensaiava os primeiros passos na ficção, portanto, o estilo de composição do escritor veio se aperfeiçoando até que ele encontrou uma forma estável de construir seus textos, em boa parte apoiado na reciclagem consciente dos recursos narrativos desenvolvidos pela tradição moderna. E esse processo de amadurecimento da linguagem é nítido quando se compara Olívia com Eles eram muitos cavalos.

Revista (Entre Parênteses) 


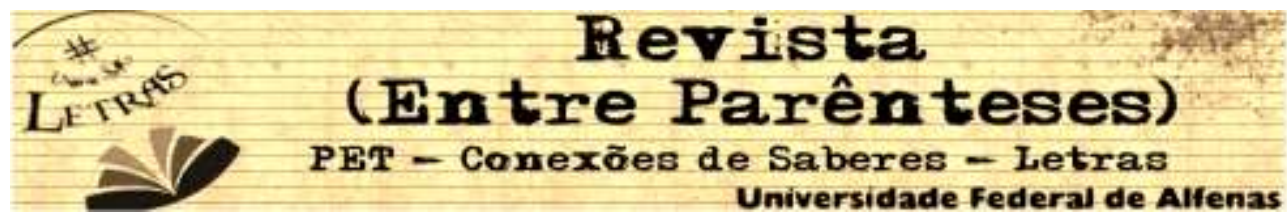

Tal comparação entre um conto e um romance faz valer a reflexão de Massaud Moisés (2006, p.37) citada na introdução. Aliás, no caso de Olívia e Eles eram muitos cavalos, o tema dos socialmente oprimidos, dos desafortunados, dos sem oportunidade de emprego, se mantém, embora transformado o caso de Francisco e Olívia no caso dos moradores da maior cidade do Brasil, São Paulo. A técnica prenunciada no conto amadurece e se aprimora até chegar ao romance, mas o esboço de configuração ficcional visível em Olívia está nitidamente presente no objeto tecnicamente muito mais refinado - quando comparado àquela tentativa inicial - que é Eles eram muitos cavalos.

Esse processo de amadurecimento da linguagem e de aperfeiçoamento do estilo de composição por que passou a obra de Luiz Ruffato se assemelha ao processo de criação de $O$ Cortiço, de Aluísio Azevedo, romance do qual certos episódios e personagens - sobretudo a própria habitação coletiva, protagonista do texto - foram testados em obras anteriores. Em crônica publicada n'O touro negro, por exemplo, já se aborda o ambiente das casas de cômodos, os cortiços e os rumores de trabalho que faziam parte da ambiência dessas habitações coletivas. Isso é o que parece ocorrer no conto Olívia em relação ao romance Eles eram muitos cavalos: no percurso técnico que vai do conto ao romance transparecem essa reflexão e esse retrabalho do próprio processo de escrita, o amadurecimento da linguagem e o refinamento da representação ficcional, o que evidentemente passa por um aprimoramento da técnica narrativa.

Evidencia-se em Olívia o ensaio de algumas das características que comporão a dicção ruffatiana na maturidade do autor. Esse ensaio de características e recursos estético-representacionais prenuncia, sobretudo, a essência da técnica empregada na composição de Eles Eram Muitos Cavalos.

O autor, em entrevista, disse que essa obra era uma "instalação literária". É a obra em que ele alcança o amadurecimento de sua técnica de construção ficcional:

No começo da década de 1980 , eu me encontrava num impasse. Decidido a me tornar escritor, e tendo claro o tema que queria perseguir, a vida operária, percebi que necessitava, antes de iniciar minha trajetória, compreender o processo da escrita como forma de expressão. Ou seja, se dominava o conteúdo, faltavam os 


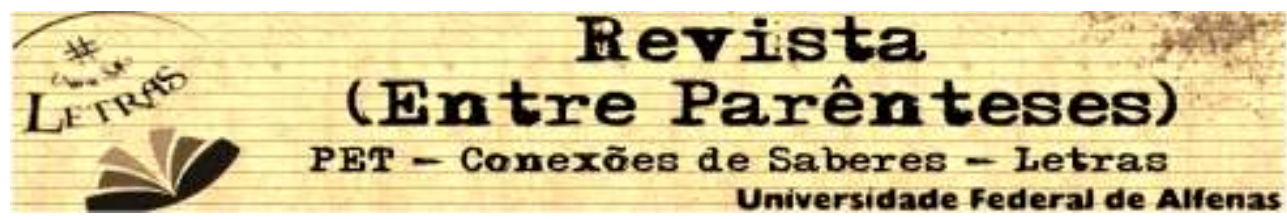

instrumentos necessários para edificar uma obra, pois para mim não fazia sentido dissertar sobre a questão do proletariado usando a forma do romance burguês, uma narrativa que, mesmo quando se quer caótica, pretende, como fim último, a ordenação do mundo. Eu desejava algo que trouxesse, como forma, a própria essência do impasse da nossa sociedade. Adiei então por quase vinte anos o projeto. Em 1998, senti-me pronto para iniciar-me como escritor: publiquei uma coletânea intitulada Histórias de remorsos e rancores, logo seguida, dois anos depois, por outra, (os sobreviventes), ambas tendo como tema a vida operária. Mas, frustrado, percebi que formalmente ainda não me satisfaziam... Somente com o lançamento, em 2001, do que chamo de -instalação literária, Eles eram muitos cavalos, um livro que tem como personagem a cidade de São Paulo, é que compreendi o que queria. (RUFFATO, 2010)

Ao que parece, essa técnica de construção ficcional vinha sendo testada desde há muito, tanto que em Olívia já se apresentam algumas maneiras de representar o real que serão, em Eles eram muitos cavalos, levadas a um grau muito mais elevado de amadurecimento e consciência técnica.

Esse amadurecimento de escrita se mostra quando, em Eles eram muitos cavalos, o autor consegue uma elaboração mais complexa das técnicas apresentadas em Olívia, bem como aumenta o repertório técnico reciclado do Modernismo. Ao que tudo indica, de Olívia até sua obra mais consagrada, Ruffato veio testando várias técnicas e linguagens até consolidar a sua própria dicção e maneira de expressão. $E$ esses testes se deram sob uma influência marcante das formas modernas:

Só que achava, ainda acho, São Paulo uma cidade inapreensível. Ela cresce desordenadamente e a paisagem muda da noite para o dia, literalmente. Não podia então usar as formas convencionais do romance burguês para tentar captar essa dinâmica. Então, busquei maneiras alternativas de compreendê-la, trazendo para as páginas do livro as várias linguagens em que a cidade pode ser traduzida: a publicidade, o jornalismo, o teatro, o cinema, a música, as artes plásticas, a descrição, a narração, a poesia... Eu não nomeio Eles eram muitos cavalos como "romance", mas sim como "instalação literária". (RUFFATO, 2008)

Eles Eram Muitos Cavalos é uma obra em que o autor enciclopediza as tendências estéticas postas em prática desde os primeiros experimentos decorrentes 


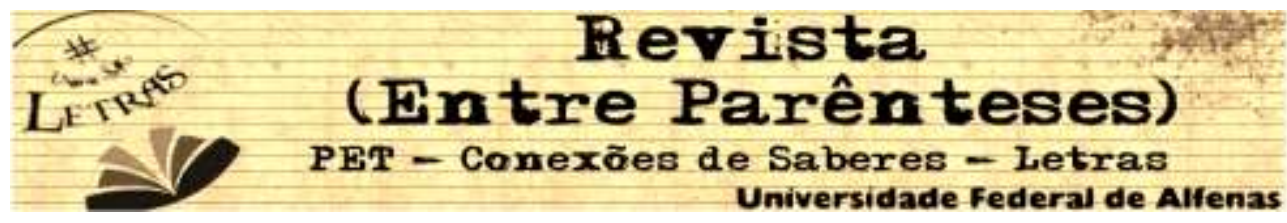

da crise da representação realista até a consciência problemática da exaustão das formas narrativas no fim do século XX. E essa enciclopedização resultou em uma reciclagem das formas empregadas pelo Modernismo, deixando transparecer suas técnicas/formas vanguardistas e, sobretudo, aquelas desenvolvidas durante o novo experimentalismo estético proposto pela literatura posterior ao golpe militar de 1964.

A reciclagem, em Eles eram muitos cavalos, se dá por meio de uma escrita oralizada, pela interpenetração dos planos discursivo-narrativos, pela alternância tipográfica, pela disposição gráfico-concretista do texto, pela escrita cadenciada e sonora, pela plasticidade da linguagem, por colagens, pelo emprego do fluxo da consciência, pela mistura de gêneros dentro do romance, pelo emprego diferenciado da pontuação e, principalmente, pela estética fragmentária do texto.

É o que ocorre, por exemplo, no fragmento 21, "ele)", do romance. O emprego diferenciado da pontuação deixa a leitura cadenciada, ritmada. O discurso das personagens (alguém que pergunta se ele não vai ao jogo de futebol e do chefe dele) se imiscui no discurso do narrador, que se mistura com o fluxo de consciência do rapaz, personagem principal do fragmento. Essa interpenetração de discursos fica marcada, em alguns momentos, pela alternância tipográfica. Tudo marcado pela escrita oralizada, carregada de empregos agramaticais típicos da fala e de palavrões. O texto adquire uma disposição gráfico-visual para dar conta da confusão entre aquilo que ocorre no plano fático/real e o que ocorre no plano do pensamento:

Dia havia era assim, um desassossegamento, lugar algum bom, formigamento excursionista, pernas mãos braços, por tudo desinteresse, pessoa nenhuma, nem conversa, cavar um buraco: trancar-se, Tem Corinthians hoje... Num vai não?, ventania emdentro da cabeça, pensamentos redemunham (...), dedos magros tamborilam o teclado, processos pareceres adendos questionários minutas memoriais de-acordos considerando demandas ligígios pleitos ações causas pendências citações agravos recursos apelações aprazamentos notificações interpelações

mas,

e o dia?

é bonito o dia? é feio?

faz frio? faz calor?

¿o vento embalou as nuvens no céu ou elas regaram mansamente o asfalto?

(...)

Revista (Entre Parênteses)

Volume 1, Número 5, 2016 - ISSN 2238-4502 


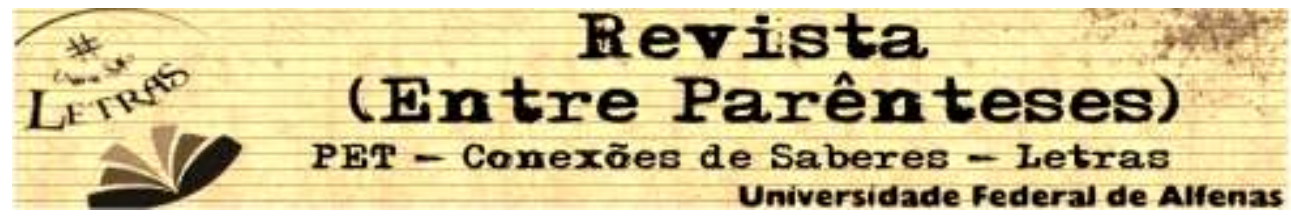

às oito horas, dentro da caixa de vidro fumê, liga o micro-computador, a mesa de pinus abarrotada, hora do almoço, devora um xis-salada da lanchonete da esquina, pudesse comia ali mesmo, mas a chefia, Estraga o teclado... Esse farelinho aqui ó, trava tudo, uma bosta! E se cai Coca-Cola então, puta!, aí fodeu, (...) (RUFFATO, 2001, pp. 50-51)

No fragmento 17, "A espera” (RUFFATO, 2001, pp. 40-41), um rapaz se prepara para sua décima entrevista de emprego em dois meses. Acorda, vai até a cozinha para tomar o café da manhã e depara com o bilhete da mãe colado na porta da geladeira:

Sem camisa, a calça de moletom cinza arrasta o chinelo-raider pelo sinteco até a cozinha. Nas trempes engorduradas do fogão-a-gás, um coador engasgado de pó-de-café mergulha num bule verde-escuro empipocado de florzinhas brancas, a espuma aerada do leite fervido cobre o campo negro do tefal, uma tampa assenta-se deselegante sobre a garganta da panela-de-pressão, restos de uma sopa Knorr galinha-caipira. Na porta da geladeira, fixado por imãs (um abacate, um chuchu e a propaganda de uma farmácia), um bilhete:

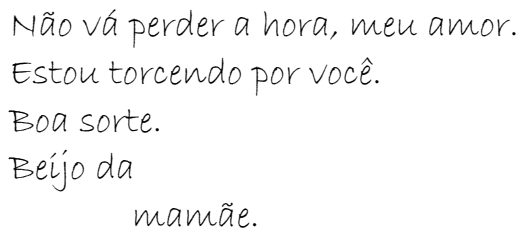

O bilhete na porta da geladeira é colado no texto, transcrito imitando graficamente o modo como a mãe o havia redigido. A fonte se altera, de modo que fique representada a grafia da mãe.

Em Eles eram muitos cavalos, como no conto, ainda podemos observar a existência também discreta de um certo lirismo. Um dos vários fragmentos do romance em que percebemos isso é "Chacina $n^{\circ} 41^{\prime}$ ", no qual um vira-lata busca seu dono, um morador de rua e catador de latinhas a quem fazia companhia. Durante a busca, o cão é agredido cruelmente por pessoas que estavam nos locais por onde passava. Ele escapa da violência à qual foi submetido e continua sua procura, quando presencia "pedaços de chumbo ricochetearem a parede": dois ou três garotos haviam morrido. O lirismo na voz do narrador dessa história é perceptível quando ele se refere ao percurso do vira-lata em busca do dono:

Parou resfolegante, o coraçãozinho às corcovas, estendeu-se sobre o corpo trêmulo, a confusa recém-lembrança. Por que fora agredido? Arfando, a língua lambe o pelo duro, amarelo-sujo, tenta escoimar os 


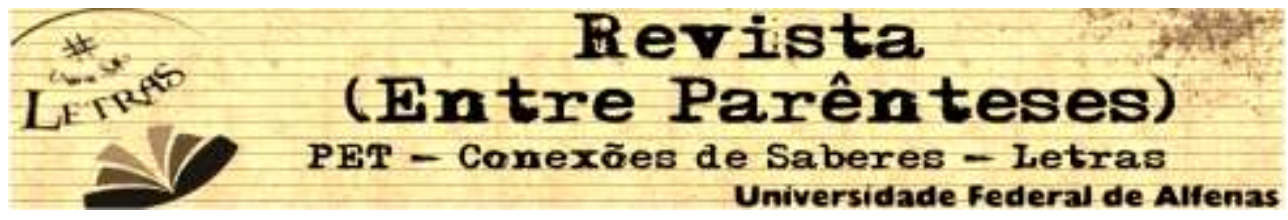

doloridos. Por quem fora agredido? Os dentes agudos mordiscam ao léu, à cata de invisíveis pulgas. Exausto, a cabeça pende sobre as patas esticadas, cerra os olhos, o rabo sossega, suspira. Aos poucos, os caquinhos coloridos assentam no fundo do caleidoscópio. Caminhava, entreabrindo cortinas da noite à procura de seu dono (...). (RUFFATO, 2001, pp.30-31)

\section{Conclusão}

Percebe-se, a partir desses elementos, que há entre Olívia e Eles eram muitos cavalos evidente continuidade. Assim como o conto, também o romance é um texto que dá ao tema dos desfavorecidos, dos socialmente oprimidos, dos insatisfeitos com os infortúnios da vida, um tratamento estético reciclado: rompe com a forma tradicional do gênero, porque sua composição formal questiona a tradição por meio dos recursos estético-representacionais buscados ao repertório formal do Modernismo. Como viria a ocorrer no romance ruffaftiano, o conto já apresenta recursos formais de representação - anacronismos, interpenetração discursiva, alternância tipográfica do texto, um lirismo que se imiscui nas vozes mais prosaicas do romance, a colagem, o emprego de uma escrita oralizada.

Olívia e Eles eram muitos cavalos, portanto, são textos concebidos pela mesma vontade de compreensão e consolidação de uma forma de expressão. No entanto, enquanto no conto o autor testa algumas técnicas que o ajudarão a encontrar sua própria dicção, no romance seu estilo já aparece mais amadurecido, mais complexo, mais variado em recursos técnicos. Olívia é claramente um protótipo da forma narrativa que se fixará na obra madura do escritor. 


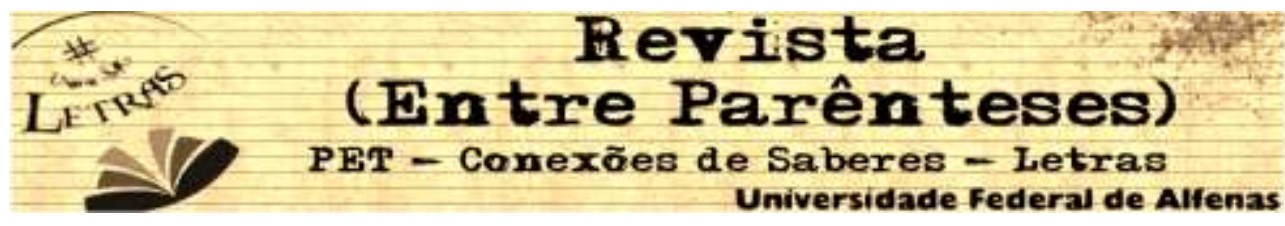

\section{Referências Bibliográficas}

ANDRADE, Oswald. Memórias sentimentais de João Miramar. São Paulo: Editora Globo, 2004.

AZEVEDO, Aluísio. O cortiço. Rio de Janeiro: Otto Pierre Editores, 1979.

. O Touro Negro. São Paulo: Livraria Martins, 1961.

ÂNGELO, Ivan. A Festa. São Paulo: Summus, 1978.

BRANDÃO, Ignácio de Loyola. Zero. São Paulo: Clube do Livro, 1986.

CANDIDO, Antônio. A educação pela noite e outros ensaios. São Paulo, Ática, 1989.

DALCASTAGNÉ, Regina. Renovação e permanência: o conto brasileiro da última década. Estudos de Literatura Brasileira Contemporânea, no 11. Brasília, janeiro/fevereiro de 2001, pp.3-17.

GALVÃO, Walnice Nogueira. Cinco teses sobre o conto. In: O livro do seminário. São Paulo: LR Editores Ltda., 1983, p.165 - 172.

JOLLES, André. Formas simples. São Paulo: Cultrix, 1976.

LISPECTOR, Clarice. Felicidade Clandestina. Rio de Janeiro: Rocco, 1998.

. Uma aprendizagem ou o livro dos prazeres. Rio de Janeiro: Rocco, 1998

LUCAS, Fábio. O conto no Brasil moderno. In: O livro do seminário. São Paulo: LR Editores Ltda., 1983, p.103 - 165.

MACHADO, Alcântara. Brás Bexiga e Barra Funda. São Paulo: Nova Alexandria, 1996.

MOISÉS, Massaud. A criação literária: prosa I. São Paulo: Cultrix, 2006.

QUEIRÓS, Eça de. A cidade e as serras. São Paulo: Saraiva, 2012.

. Civilização e outros contos. Belo horizonte: Moderna, 2004.

RAMOS, Graciliano. Vidas Secas. Rio de Janeiro: Record, 2006. 


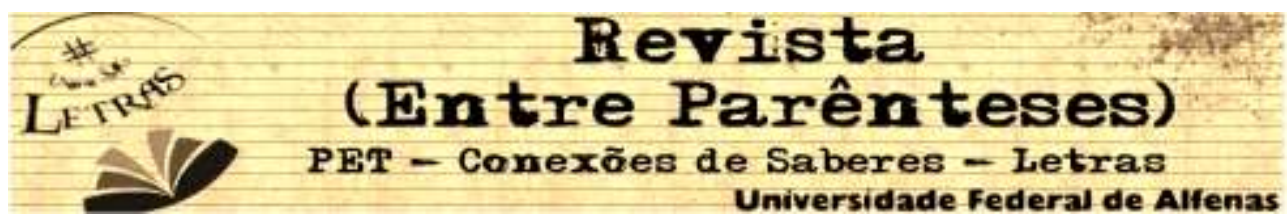

RUFFATO, Luiz. Depoimento. Jornal dos Lagos, Suplemento Literário, Alfenas, ํㅜ de edição 0042, p.15, Julho, 1984.

Eles eram muitos cavalos. Rio de Janeiro: Record, 2001.

. Entrevista exclusiva com Luiz Ruffato. Entrevistador: Rinaldo de Fernandes. Disponível em <http://rinaldofernandes.blog.uol.com.br/arch2008-0427_2008-05-03.html>. Acesso em: 22 ago. 2014.

. Olívia. In: Marginais do pomba. Cataguases: Fundação Cultural Francisco Inácio Peixoto, 1985.

Perguntas a Luiz Ruffato. Entrevistadores: Marcos Vinícius Ferreira de Oliveira e Rodrigo da Silva Cerqueira. In: Estamos sempre indo para casa: breve análise do inferno provisório, de Luiz Ruffato. Universidade Federal de Juiz de Fora, Juiz de Fora, 2010. 